\title{
THE RIGHT OF THE PUBLIC ON PUBLICLY HEARD AND OPEN CRIMINAL PROCEEDINGS IN THE CONTEXT OF PREVENTING CORRUPTION AND ECONOMIC CRIME BY JUDICIAL POWER
}

\author{
Mykhailo Vilhushynskyi ${ }^{1}$, Lidiia Moskvych ${ }^{2}$
}

\begin{abstract}
The purpose of the paper is the system analysis of legal, organizational, and procedural mechanisms of the realization of the right of the public and mass media on their participation in transparent and open criminal proceedings in the context of preventing corruption and economic crimes within the system of judicial power, as well as the development of scientifically substantiated recommendations for the improvement of the current legislation of Ukraine on the judicial system taking into account the most advanced international practices. The interconnectedness of effective implementation of the principles of transparency and openness of criminal proceedings with the restoration of trust in the judicial system from the side of civil society has been substantiated. Methodology. To solve the tasks set in the dissertation, the authors have used a complex of general and special scientific methods. Logical and cognitive methods (analysis, synthesis, induction, and deduction) made it possible to study general conditions for the organization and procedure of the implementation of the principles of transparency and openness during the cassation appeal of decisions in criminal proceedings. The system and structural method has assisted to determine the essential and content characteristics of the principles of transparency and openness within criminal proceedings, as well as to reveal their significance and correlation while ensuring the judiciary by the cassation court. The formal and legal method made it possible to reveal the proper legal procedure for implementing the principles of transparency and openness during the criminal proceedings by the cassation court. Modelling method allowed determining the ways to improve the legislation on the judiciary and criminal procedural legislation in part to more effective implementation of the principles of transparency and openness in the criminal procedure of Ukraine. The comparative and legal method was used in clarifying the relationship between the levels of domestic and international legal regulation of the implementation of the principles of transparency and openness of criminal proceedings. Experimental methods were used to construct grounded theoretical and applied provisions that adequately reflect the features and interrelations of the processes of implementing the principles of transparency and openness within criminal proceedings, confirmation or refutation of certain concepts, views, their examination by means of thought or subject experimentation based on practice criteria. Result of solving this purpose is to form the author's understanding that members of the public (the general public) and mass media cannot be holders of jurisdictional rights, that is, those rights that are exercised in the course of court proceedings by involved persons as a result of their criminal procedural status (parties and other participants in criminal proceedings). That is, members of the public and the general public, as well as members of mass media, who are not entitled to the right for public court proceedings but are subjects to the right to obtain information about public court proceedings, the administration of transparent and open justice. Practical implications. Ensuring reliable public control over the judiciary through the widespread use of mass media will effectively prevent corruption and commission of economic crimes by the judges. Value/originality. Amendments and alterations to the national legislation on the judiciary and the Criminal Procedural Code have been offered, which would facilitate the more effective implementation of the right to transparent and open court proceedings by the public and mass media, ensure public control over the judiciary in the exercise of its procedural activities, and guarantee the right of every one to obtain information on the administration of justice in line with European standards.
\end{abstract}

Key words: publicity principle, transparency principle, corruption, economic crimes, criminal judicial system, criminal procedure.

JEL Classification: K13, K14, D73

\footnotetext{
Corresponding author:

${ }^{1}$ Taras Shevchenko National University of Kyiv, Ukraine.

E-mail: m.vilgushynskyi@ukr.net

${ }^{2}$ Yaroslav Mudryi National Law University, Ukraine.

E-mail: moskvichlida@gmail.com
} 


\section{Introduction}

Forming the general idea of the role and place of the public in implementing the principles of transparency and openness in the provision of criminal justice, one must proceed from the assumption that the right to publicjustice, as well as the constitutional right to judicial protection, to its immediate implementation, exists as a general relationship between the state and individuals and is the constitutional and legal relationship. The content of this relation is the state's duty to create the necessary conditions for the transparent and open court proceedings, which include: adoption of legislation, which forms the basis for the implementation of the principles of transparency and openness, including the consolidation of the right of any person to be present at an open court hearing; elaboration of courts acts, which determine the procedure of unimpeded access of any person to an open court hearing; the possibility for citizens to receive objective and reliable information about the activity of specific courts and the functioning of the judicial system in the whole; creation and improvement of the system of placing court decisions in the Internet network and ensuring the access of a wide range of people to these decisions; placement of courts in buildings that meet modern requirements for the execution of justice and provide the opportunity for all those wishing to be present at an open court hearing (Tatsii, Hroshevyi, Kaplina, Shylo, 2013).

According to sociological surveys, in particular, the Global Corruption Barometer from Transparency International and the Gallup International Association, Ukrainians consider judicial power to be the most corrupted area (66 percent). Similar results have been repeatedly confirmed by the studies conducted by the Ukrainian Centre for Economic and Political Studies named after Oleksander Razumkov: Ukrainians consider judicial power to be the most corrupt, and about 50 percent of those polled believe that corruption covered everything within judicial power. And according to the World Justice Project (Rule of Law Index), Ukraine in the field of "lack of corruption" in the judicial system constantly occupies the last place among the analysed countries. According to the Court Index defined by the European Business Association, judicial power discredited itself among the business environment, since the estimate of judicial proceedings in Ukraine is negative according to all the components of the index (Fluri and Badrak, 2016).

One of the main causes for the destruction of the judicial power, according to which Ukraine is not able to recover by this time, is judicial reform unsuccessfully implemented in 2010: the adoption of the Law of Ukraine "On the Judiciary and Status of Judges" negatively affected the agencies of judicial selfgovernment - they became completely dependent on political power. The political principles of the formation of the Supreme Council of Justice and unambiguously formulated grounds for bringing to disciplinary liability have led to the fact that judges have actually lost the guarantees of independence of their activities. The mechanism of selecting judges was characterized by abuses by the authorities responsible for this procedure (Fluri and Badrak, 2016).

Therefore, the first step in reforming the judicial power was the adoption of the Law of Ukraine "On Restoring Confidence to the Judicial Power in Ukraine" (Law, 2014) on April 8, 2014, which contributed to the creation of legal preconditions for the self-purification of the judicial power with the direct participation of the public.

Over the past 15 years, after the so-called "small judicial reform", probably, no other principles of the criminal procedure have undergone such a transformation in Ukraine as the principles of transparency and openness of court proceedings and its full recording by technical means. Moreover, the main innovations were related not so much to the normative consolidation of the content of these principles of criminal proceedings but with the emergence of new forms of their implementation.

In particular, one can agree with the opinion of V. V. Korol and distinguish three main stages of modern reform of the principles of transparency and publicity of court proceedings (Korol, 2015).

The first stage is related to the adoption of the Law of Ukraine "On Access to Court Decisions" (Law, 2005), according to which the State Judicial Administration of Ukraine ensures the maintenance of the Unified State Register of Court Decisions.

The creation of an official web portal "Judicial Power" can certainly be considered as the second stage. This portal contains information on the list of cases to be considered; on the list of appeals (cassation) complaints; regarding the stages of court cases and reports on automated distribution, etc. This electronic resource was created based on the Regulation on the organization of access to public information held by the State Judicial Administration of Ukraine developed in compliance with the Law of Ukraine "On Access to Public Information" (Order, 2011).

The third stage is related to the activities of new nongovernmental organizations of control, in particular, public organizations, whose purpose is to facilitate the speeding up judicial reform, increase the level of transparency of the judiciary and restore the trust of our citizens to the judicial power. The regulatory framework for the activities of such organizations is the laws of Ukraine: "On Information" (Law, 2011), "On Restoring Trust in the Judicial Power in Ukraine" (Law, 2014), "On Ensuring the Right to a Fair Trial" (Law, 2015), "On the Prevention of Corruption" (Law, 2014), "On the Judiciary and the Status of Judges" as amended on June 2, 2016 (Law, 2016). However, it must be admitted that the adoption of new legislation on the judiciary 
and the status of judges has not solved the problem of corruption in the judicial system yet.

Problems of the participation of public and mass media in criminal proceedings, taking into account the principles of transparency and openness, were studied in the scientific works of such national and foreign scholars as: A. D. Boikov, L. I. Budnikova, D. A. Holovanov, Yu. A. Horinov, I. S. Hritsenko, Yu. M. Hroshevyi, V. V. Korol, A. A. Levy, Z. V. Makarova, V. T. Maliarenko, O. O. Ovsiannikova, A. P. Petryshyn, I. L. Petrukhin, M. A. Pohoretskyi, S. V. Praskova, S. V. Prylutskyi, P. I. Repeshko, A. H. Richter, S. V. Romanov, Yu. S. Sida, O. V. Smirnov, O. H. Yanovska, and others. At the same time, the issue of public control in the courts of all instances and the implementation of the relevant provisions of the Law of Ukraine "On the Judiciary and Status of Judges" (Law, 2016) and the Art. 27 of the Criminal Procedural Code (CPC) of Ukraine (Code, 2012), has not been adequately covered in the special scientific literature yet.

\section{Public control over the judiciary - an instrument for combating corruption}

The right to a transparent and open trial in a particular criminal proceeding is transformed into the subjective right of the participants of the process, the realization of which depends on the right of representatives of the public and mass media.

At the same time, the right to a public trial, being a subjective reflection of the constitutional principle of publicity of justice, has its own content and subjects of implementation. At the same time, the content of this right is closely linked to the role played by a person in a particular court proceeding - whether it is a party to the process or a representative of the public, an outside listener.

Therefore, the specificity of the subject structure is due to the fact that, based on the principle of the transparency and openness of court proceedings, the representatives of the public have the right to participate in the process for the purpose of exercising public control over the administration of justice (Petryshyn, 2017).

At the same time, the paradox is that public representatives, as the main recipients of the principles of transparency and openness, are devoid of the mechanisms for their protection since only the parties and other participants in the criminal process have the right to appeal against court decisions made on the basis of court hearing conducted in violation of these principles.

However, the peculiarity of the realization of the right to the transparent and open criminal proceedings is the inability of its carriers to abandon it since this right equally belongs to both parties of the process (Petryshyn, 2017). Thus, the parties, other participants in the criminal proceedings, representatives of the public, the media in the same trial have different interests and reasons for refusing to the publicly heard trial.

The right to a public trial is an important component of the implementation of the principles of transparency and openness of the criminal process, and therefore, is the basis for the realization of the rights of society members, including representatives of mass media, to participate in court proceedings as third-party observers (the general public). That is, the rights of the public to access an open trial are derived from the right of the parties to the public (transparent and open) judicial proceedings.

Moreover, representatives of the public (the general public) and mass media not being the parties to the criminal process, cannot be the bearers of jurisdictional rights, i.e., those rights that are implemented in the course of judicial proceedings by the persons involved in it as a result of their criminal procedural status (parties and other participants in the criminal proceedings).

The principles of transparency and openness for the public are important prerequisites for exercising control over judicial power. In turn, public control is one of the ways for citizens to participate in the state administration. Therefore, summarizing the normative requirements of the legislation on the judicial system and the current CPC of Ukraine, the publicity and openness of court proceedings for persons who are not participants in the criminal process, include: 1) the right to receive information on the date, time and place of trials; 2) the right to equal access to the court building, the office, the courtroom; 3 ) the right to attend a public trial, including the right to be present at the announcement of court decisions; 4) the right to get acquainted with court decisions; 5) the right to record the content and progress of the process in writing or by audio recording without special court authorization; 6) the right to disseminate information about events that took place during an open trial to unlimited number of persons, to reproduce legally, with the observance of the law, the materials received, to demonstrate and publish them; 7) the right to public discussion (including in the mass media), criticism of court decisions and actions of the court, carried out in the course of open court proceedings.

Further improvement of the financial control over the activities of courts and judges is equally important from the point of view of ensuring the openness of the judicial system in Ukraine, as rightly pointed out by M. A. Pohoretskyi and O. H. Yanovska. In particular, they analyse the Law of Ukraine "On the Judiciary and Status of Judges” dated from July 7, 2010, No. 2453-VI, which provided the mandatory publication of copies of declarations of judges on property, income, expenses, and financial obligations for the last year on the official web portal of judicial power of Ukraine (www. court.gov.ua). The above provision should provide unhindered access of the public to the aforementioned 
information about the property of a particular judge with the purpose of carrying out independent public control in the field of prevention and counteraction to corruption. However, on April 24, 2012, the said Law was amended, according to which judges were no longer obliged to file a declaration on the property, income, expenses, and financial obligations for the last year for publication on the Internet. Such amendments have led not only to a reduction in the level of financial control over the activities of courts and judges but also virtually destroyed the judicial system of Ukraine. Therefore, we fully share the thoughts of M. A. Pohoretskyi and O. H. Yanovska that in spite of objectively existing difficulties, the system of financial control, which continues to be built, should become an effective mechanism for preventing corruption in the judicial system, giving an opportunity to avoid competitive interests and to ensure the transparency of the activities of the courts (Pohoretskyi and Yanovska, 2013).

In this context, one should agree with the position of O. V. Smirnov that the restructuring of the judicial system in order to maximally bring it closer to its own people can be a mean of fighting of the most passionate part of citizens against corruption and an effective way of upbringing the state apparatus (Smirnov, 2004). This will make it possible to eliminate socio-political tensions in society and to take measures to reform the judicial system in an evolutionary way. In particular, such measures in line with European standards should include:

- reduction of the amount of judicial immunity and providing a judge with only functional immunity (immunity from charges of actions committed in the course of performing judicial functions);

- settlement of issues concerning the prevention and resolution of competitive interests in the activity of representatives of judicial power;

- determination of the peculiarities of conducting a special examination of candidates for a judge's position; - submission, disclosure (in particular on the Internet), and monitoring of the reliability of the data of judges' declarations on property, income, expenses, and financial obligations;

- conduction of periodic training of judges on the matters related to standards of counteraction and prevention of corruption, taking into account them during the certification of judges (Fluri and Badrak, 2016).

The main place among other components of the implementation of the principles of transparency and openness has the right to receive information on the date, time, and place of trials, which follows from paragraph 2 of the Art. 11 of the Law of Ukraine "On the Judiciary and Status of Judges" (Law, 2016) and paragraph 1 of the Art. 27 of the CPC of Ukraine (Code, 2012). The transparency and openness of judicial activity are initial components, as noted in the legal literature (Leonenko, Miller, Siryi, Chanhuli, 1993). In this case, the message must contain a clear indication for the date and place of the court hearing, that is, the answer to one of the issues to be resolved in regard to the preparation for a trial (Korol, 2015).

At the same time, the current CPC of Ukraine does not fully resolve the issue of the forms for notification about designated criminal proceedings. Thus, Part 1 of the Art. 135 of the CPC of Ukraine regulates only the procedure for calling the participants of criminal proceedings: "A person is called to an investigator, a prosecutor, an investigative judge, a court by handing the call for a summons, sending it by mail, e-mail or facsimile, making a call by telephone or by a telegram".

A similar provision is contained in clause 16.3 of the Instruction on record-keeping in local general courts, appellate courts of regions, appellate courts of Kyiv and Sevastopol, the Court of Appeal of the Autonomous Republic of Crimea, and the Supreme Specialized Court of Ukraine for the consideration of civil and criminal cases, approved by the order of the State Judicial Administration of Ukraine dated December 17, 2013, No. 173 (Order, 2013).

However, neither the CPC of Ukraine nor the abovementioned Instruction on the record-keeping stipulates the procedure for notifying citizens who are not participants in criminal proceedings, about the time and place of a trial. Therefore, we fully support the suggestion of V. V. Korol that the content of notification on criminal proceedings, intended for the court hearing of the relevant instance requires filling of such a gap and its legislative affirmation in the CPC of Ukraine (Korol, 2015).

An innovative step in achieving transparency and openness of court proceedings is that citizens who want to familiarize themselves with criminal proceedings that are to be heard in court, in a matter of minutes, without leaving their home, can find out the date, place and time of the court hearing on the official web portal "Judiciary of Ukraine".

Such a network information resource greatly enhances the possibility of implementing the principles of transparency and openness in the field of criminal justice since nowadays a significant part of Ukrainian citizens have access to the Internet. The provisions of Part 1 of the Art. 27 of the CPC of Ukraine to provide information about the time and place of a trial are realized through the web portal "Judiciary of Ukraine". Therefore, we fully agree with the idea that the content of such notifications, as well as the procedure of their placement on the web portal (through the automated system of court documents), should be regulated at the level of law (Korol, 2015).

This allows obtaining the necessary information about trials in criminal proceedings at any time convenient for citizens but not only during the court hours. For example, the information on the list of criminal proceedings (cases) for consideration in the Cassation Criminal Court is available at: https://supreme.court. 
gov.ua/supreme/gromadyanam/kks/ and by calling the contact centre 0-800-501-492. Besides, the official electronic address of the Cassation Criminal Court ksk@supreme.court.gov.ua - operates for the purpose of sending correspondence.

However, there is a need in the printed version of the list of cases for consideration, which is posted in the court building for the participants of the criminal proceedings and other persons who wish to be present at the trial. The legal literature repeatedly puts forward propositions that we fully support, about the need to post an announcement (lists of criminal proceedings) from the outside of the court building (Boikov, 1989; Korol, 2015; Makarova, 1993; Petrukhin, 1981; Shushanashvili, 1969).

According to V. T. Maliarenko, the open nature of a trial on criminal proceedings in the courts of all instances also means that all procedural actions must be carried out by the court at open doors, except for the meeting of judges while deciding a sentence or making some decisions (Maliarenko, 1998). Therefore, for the proper implementation of the principles of transparency and openness of litigation, the rule that a judgment is publicly proclaimed (Part 7 of the Art. 27, and Part 1 of the Art. 376 of the Criminal Procedural Code of Ukraine) is of paramount importance.

In terms of open trial, the abovementioned norm provides the disclosure of the results of the court's work, which takes place in the counselling room, and hence the integrity of the trial for accessible perception by all those present in the courtroom (Korol, 2015). Therefore, the activity of the court for the administration of justice, due to its transparent and open nature, is under the control of public opinion, the public. Public opinion assesses the verdict and the internal conviction of judges in terms of their compliance with the requirements of the law, norms of morality (Korol, 2003). That is why, according to Yu. M. Hroshevyi, approving the verdict of the court, considering it to be fair, public opinion strengthens the educational effect of criminal proceedings (Hroshevyi, 1972).

The legal basis for access to court decisions is the Laws of Ukraine "On Access to Court Decisions" (Law, 2006) and "On Implementation of Judgments and Practices of the European Court of Human Rights" (Law, 2006). In accordance with the provisions establishing the availability of court decisions, everyone has the right to have access to court decisions in accordance with the procedure established by the law. The State Judicial Administration of Ukraine ensures the maintenance of the Unified State Register of Court Decisions in order to have access to court decisions of the courts of general jurisdiction. Thus, the Procedure for maintaining the Unified State Register of Court Decisions was approved by the decision of the Supreme Council of Justice dated April 19, 2018, No. 1200/0/15-18 (Decision, 2018).

Court decisions registered in this Register are open for free round-the-clock access on the official web portal of the judicial power of Ukraine. The opinion of $\mathrm{O}$. O. Ovsiannikova is quite right, in the context of the subject matter of the research, who emphasizes that only those decisions that have come into force have legal effect to be published in the Register. The text of such a decision should indicate whether an appeal or cassation was filed against this decision, what the grounds are and what decision was taken by a higher court. Regarding the inclusion of all intermediate acts of the judicial power into the Register, such acts cannot be of interest to users of the Register since they do not affect the results of the trial and judicial statistics, and therefore, there is no need for it. At the same time, the issue about the terms of preserving court decisions in the Register remains relevant (Ovsiannikova, 2009).

At the same time, one should admit that the Register is rather inconvenient to use since in order to find a solution, it is necessary to know precisely the court that passed it, the date of the decision or the registration number in court or the Article of the Criminal Code of Ukraine, according to which a person was convinced. The lists provided by the search system do not specify a category of the case. If it is necessary to get acquainted with the court practice of a certain category, users (both a judge and a regular citizen) are forced to search through all the decisions. Considering the number of courts in Ukraine and the amount of cases they consider daily, it becomes unrealistic. Obviously, it will be necessary to classify the decisions in the Register, to improve the technical possibilities of their search according to different criteria.

A separate procedure for ensuring the availability of court decisions has been established in relation to decisions of the European Court of Human Rights in the case against Ukraine, which found violations of the Convention for the Protection of Human Rights and Fundamental Freedoms (Convention, 1950), decisions on just satisfaction in cases against Ukraine, decisions on final settlement agreement in cases against Ukraine.

One of the most striking examples of effective public control in the field of legal proceedings is the activity of the public organization "Open Court". Its members (activists) on a voluntary basis carry out video and audio recordings in the courts, professional processing and installation of recorded material, as well as its analysis and review. The implementation of this project became possible only since March 28, 2015 - with the entry into force of the new Law of Ukraine "On Ensuring the Right to a Fair Trial” (Zakon Ukrainy vid 12 liutoho 2015 roku № 192-VIII), which guarantees the possibility of taking photos, video and audio recordings in the courtroom using a portable video, audio equipment without obtaining a separate court authorization. The material shot is broadcast on the website of the "Open Court" video channel, where the video file is formed and the analysis and provision of legal assessment of court cases are realized, to the professional level of participants in 
a trial (a judge, a prosecutor, a lawyer). The purpose of this project was to increase the trust of citizens and strengthen the authority of the court, increase the professional level of judges, lawyers and prosecutors (Korol, 2015).

It is also important that this organization can work on citizens' requests for assistance provided on a royaltyfree basis. The public initiative of the "Open Court" is expressed, in particular, in the creation of versatile special projects, namely: "Open Court Reporter", "Loud Deed", "Judicial Raid”, "Judge-Antihero". The uniqueness of this project is underlined by the fact that no other European state has the same practice. Ukraine is actually a kind of experimental site in this area. The project partners from the European Union and the United States regard the "Open Court" activity as a key element in combating corruption and injustice in the courts and believe that Ukraine's success can serve as an example for the application of such a mechanism in other countries of the world.

Many NGOs and projects are based on international support and assistance. One such project in the field of interaction between the public and the judiciary is the "Fair Justice" project, funded by the United States Agency for International Development (USAID), and has been operating in Ukraine since October 2011. The project aims to improve legislation, complete judicial reform and improve judicial practice. Improving judicial practice means raising the transparency of the court and the trust of the community. The main task of the project is the implementation of the laws of Ukraine: "On Purification of Power" (Law, 2014) and "On Restoring Confidence in the Judiciary" (Law, 2014). In particular, the "Fair Justice" organization is one of the founders of the Internet platform "Electronic Court" (Korol, 2015).

The Public Council for Integrity is a very effective project of public control over the activities of courts and judges in Ukraine. In January 2019, this Council approved the indicators for determining the inconsistency of judges (candidates for a position of a judge) with the criteria of integrity and professional ethics. The press release of the Council states that the document was developed based on the best international practices in the field of judicial integrity and ethics, as set out in the Bangalore Principles of Judicial Conduct, their comments, recommendations of the Committee of Ministers of the Council of Europe, the conclusions of the Venice Commission and the Advisory Council of European Judges, and also taking into account the provisions of the Code of Judicial Ethics, the Guidelines of the Public Council of International Experts on the assessment of the integrity, knowledge and practical skills of candidates for positions of judges of the Supreme Anticorruption Court (The Center for Training Judges, 2019).

Indicators are also based on previous practice of the Public Council of Integrity and take into account the results of their agreement with the High Qualifications
Commission of Judges of Ukraine. The content of the document takes into account the views of experts from the Council of Europe, the European Union, and the USAID "Fair Justice" program.

This list of indicators of compliance with the criteria of integrity is indicative and cannot be interpreted as exhaustive (in particular, the criteria of integrity include: independence, impartiality, honesty and integrity, ethical standards, equality, and diligence). The list of indicators will be replenished during the work of the Public Council of Integrity. The Public Council of Integrity will also rely on the practice of the Public Council of International Experts.

We should distinguish the following several indicators demonstrating discrepancy to the criterion of honesty and integrity of a judge (candidate for a judge's position) and can testify to corruption:

- a judge (candidate for a judge's position) deliberately or as a result of obviously negligent attitude towards the performance of his duties has reported unreliable (including incomplete) information in the declaration of integrity, for example, concealed information about the offense, manifestation of unfair behaviour, interference with the activity of a judge, etc.;

- a judge (candidate for a judge's position) deliberately or as a result of obviously negligent attitude towards the performance of his duties has reported unreliable (including incomplete) information in the declaration of family ties, for example, concealed a family member, a close relative or a person with whom there were competitive interests or who made dubious gifts or who received significant income from a dubious origin with the participation of the declarant or has a property relationship with the declarant or a person and the declarant have mutual existing obligations, etc.;

- a judge (candidate for a judge's position) did not report the existence of competitive interests and/or did not take other measures to prevent it (Smirnov).

At the same time, "transparency of justice" is a special problem since it has not only legal but also, above all, political character. The state and civil society have not become equal partners yet, but only intend to become them. Therefore, we are fully convinced of the correctness of the position of I. S. Hrytsenko and S. V. Prylutskyi, that the judiciary is not fully prepared for such a perception of the tasks of justice yet (Hrytsenko and Prylutskyi, 2015).

Publicity or openness of justice is a much deeper concept than a mere public and open trial or public announcement of a sentence. Essentially, it is the priority of civil society over the state in legal proceedings (Smirnov, 2003).

It is the search for a balance between the state and civil society that encourages such mechanisms of organization of judicial power that will reflect their joint compromise. We believe that such a compromise between the state and civil society in matters of 
organization of judicial power and the administration of justice can be realized, first of all, in the form of active civilian control.

Legal and social practices have developed certain forms of control of the society over justice: publicity of the procedure of legal proceedings; democratic procedure for the formation of the judicial system and the judiciary; public awareness about the mechanism of functioning of the judiciary, the decisions it has made, the purpose and personal qualities of its representatives, as well as the publicity and openness of all these issues in the framework of public discussion (Tatsii, Hroshevyi, Kaplina, Shylo, 2013). Thus, public control over the judiciary should be carried out through the openness of the justice process (transparency and openness of legal proceedings), the availability of mass media to judicial information and its objective coverage.

Taken together, this forms openness and transparency of justice. Therefore, as O. O. Ovsiannikova rightly focuses, the transparency of judicial power is a necessary condition for effective public control (Ovsiannikova, 2008).

The duty of the court to notify the case in this aspect is relevant, and the open nature of the court proceedings must be enshrined in the procedural law of Ukraine in accordance with clause 1 of the Art. 6 of the Convention for the Protection of Human Rights and Fundamental Freedoms (Convention, 1950; Ovsiannikova, 2009).

The new wording of Part 4 of the Art. 11 of the Law of Ukraine "On the Judiciary and Status of Judges" (Law, 2016) stipulates that the participants of the trial, other persons present in the courtroom, representatives of mass media may hold a photo, video, and audio recording in the courtroom with the use of portable video and audio technical means without obtaining a separate permission of the court but taking into account restrictions established by the law. The broadcast of the court hearing is carried out with the permission of the court. Conduction in the courtroom of photographing, video recording, and broadcasting of court hearing should be carried out without hindering the conduct of the proceedings and the implementation of their procedural rights by the participants in the court proceedings (Code, 2012). By introducing the novel about the use of portable video equipment without the permission of a judge, the legislator significantly expanded the scope of the implementation and the principle of publicity of criminal proceedings. At the same time, Part 6 of the Art. 27 of the CPC of Ukraine states that everyone who is present in the courtroom can conduct a transcript, make notes, use portable audio recorders. Conduction in the courtroom of photographing, video recording, broadcasting of court hearing on radio and television, as well as performing sound recording with the use of stationary equipment, shall be allowed on the basis of a court order, which is made taking into account the opinion of the parties and the possibility of conducting such actions without prejudice to judicial proceedings. Consequently, there is a legal conflict, as the CPC of Ukraine explicitly foresees the use of only portable audio recorders without the permission of a judge. Therefore, in practice, there were often situations where judges denied citizens the right to conduct video filming, referring to procedural law. And representatives of the public project "Open Court" argued about the illegality of such court decisions, referring to the fact that the law on the right to a fair trial "allows video recording without additional authorization of the court" (Korol, 2015). Therefore, it would be logical to introduce norms that would oblige the court to fully record the trial by technical means, even in the absence of petitions from the parties in this regard. Moreover, the mentioned novel of the Law of Ukraine "On the Judiciary and Status of Judges" and certain directions of activity of the public project "Open Court" generate a number of problematic aspects.

One of these aspects, according to V. V. Korol, is the psychological readiness of both judges and other participants of criminal proceedings for video shooting. Thus, the participants in the criminal proceedings actually become "stars" of the television and the Internet, and not everyone can cope with such a peculiar psychological pressure. It is worthy of attention a wellknown example of the judge R. V. Kyrieiev in the socalled "Gas Case" of Yu. V. Tymoshenko (Korol, 2015).

This issue was raised during the Soviet period, and it was already emphasized that everyone was individually concerned with the fact that he was taken to the camera: there were judges whose video was distracting from the process, did not make it possible to concentrate all the attention on the trial and made them think only of how they looked like (Levi, 1983). Only in 2014, the National School of Judges of Ukraine began the work on the professional psychological training of candidates for the position of a judge, as well as acting judges (there was the course "Professional psychological adaptation to judicial activity"). Therefore, we fully share the opinions of some scholars who consider it necessary to pay particular attention to the training of judges to cooperate with mass media representatives and their (judges) psychological adaptation in order to be in the focus of journalists and video cameras (Hrytsenko and Prylutskyi, 2015; Korol, 2015).

In addition, the presence of people with video cameras (including journalists) during the court hearing may be the cause of the closed behaviour of a witness, a victim, an accused, and other participants in the proceedings. This is due to both the psychological characteristics of a particular participant in the proceedings, and his reluctance to widely publicize certain information (Leonenko, Miller, Siryi, Chanhuli, 1993; Korol, 2015; Makarova, 1993). Thus, such practically unlimited possibilities for all those present in open court to freely pursue photography, video and audio recordings using portable video and audio equipment can negatively affect the establishment of truth in the case. 
Another aspect concerns the organization of placement of the public, members of public organizations and media representatives in the courtroom. Thus, Art. 27 of the CPC of Ukraine states that the court is obliged to allow all those who wish to be at the hearing, and this possibility is limited only to the number of places available to the public. For example, there are four courtrooms in the Cassation Criminal Court within the Supreme Court with the required number of seats, three of which are equipped with videoconferencing and two of them have places for the custody of the accused (defendants) and convicts.

However, there is the question: does this act itself create obstacles to an open court process? Equally important is the determination of the number of media representatives allowed for a court hearing. Therefore, we completely share the warnings of V. V. Korol that "excessive attention" of journalists can adversely affect the organization of judicial review, create obstacles in the implementation of the procedural rights and obligations by the parties of the proceedings (Korol, 2015).

\section{The role of mass media in ensuring transparent and fair justice}

Finally, the media plays an important role in the relations between judicial power and civil society, as well as have a great influence on the formation of public consciousness, public opinion on certain socio-political phenomena or processes. According to Yu. S. Sida, the media carry out a socio-judicial role, that is, one way or another, assign a function of open reflection on certain aspects of the activity of the court from the point of view of rights of judgment (Sida, 2005).

At the same time, the media form a public opinion on the activity of judicial power. And such a public discussion is an embodiment of the constitutional principle of freedom of thought and speech and must meet the requirements of the Art. 34 of the Constitution of Ukraine (Constitution, 1996). In this sense, the idea of I. S. Hrytsenko and S. V. Prylutskyi looks thoughtful that the freedom of the media may be limited in order to prevent the abuse of freedom of speech, while not introducing any censorship (Hrytsenko and Prylutskyi, 2015).

For more meaningful communication between judicial power and the public, the use of such social technologies as polling of public opinion is required; organization and conduction of meetings with the public; TV performances by "first persons" representing judicial power of Ukraine; conduction of TV debates; information impact on citizens through the Internet, etc. Therefore, we are quite convinced that the ideas of Yu. S. Sida that the application of these technologies should enable judicial power to strengthen the system of state power, increase its authority, support the principle of public relations (Sida, 2005).
However, in today's conditions, there is mutual distrust and suspicion in relations between the media and judges in our country. This distrust on the part of judges can also be explained by the hypertrophied sense of professional sovereignty, an attack on which is considered inadmissible. In turn, journalists, endowed with the right to free review and coverage of social processes in the mass media, cannot tolerate the restrictions imposed on them in relation to realizing the right to freely collect and disseminate information and to have unrestricted access to them (Hrytsenko and Prylutskyi, 2015).

Therefore, there should be a special emphasis among other things on such a category of subjects as journalists and media representatives since they are endowed with wider rights stipulated to freedom of search, receipt, and dissemination of information. Therefore, international documents and practice of the European Court of Human Rights emphasize that the media have both the right to provide information and are obliged to do so in the context of realizing the right of citizens to receive publicly relevant information.

It is believed that in this case, it is not a matter of duty as a measure of proper conduct, where there is legal liability for its failure, but about the moral and political responsibility of journalists in a democratic state, conditioned on their professional duty.

Thus, as Yu. S. Sida correctly notes, there is the transformation of journalists' freedom in public power, which is perceived by the court as an attack on the immunity of the judiciary (Sida, 2005).

At the same time, it is difficult to agree with the position of those scholars who do not include the principles of transparency and openness in the content of the broad public and especially of the media representatives to inform the public of all that is happening in the courtroom. Thus, S. V. Praskova notes that "such powers characterize the movement of information in the middle of civil society, but on the contrary, it is the element of the general social phenomenon of publicity, but not the openness of justice" (Praskova, 2004).

We firmly believe that it is difficult to imagine the implementation of the principle of transparency of justice outside the "circulation of information about justice" in society. The purpose and essence of the principle of publicity are devoid of any meaning without informing the broad (unlimited) range of persons about the functioning of judicial power, bringing the information (including information about events taking place during the trial) to representatives of Ukrainian society. And openness makes it possible to transfer information from those who "first hand" (directly, while being in the court) received it, to others, especially important for the media.

Therefore, will justice be transparent and open, is it possible to consider these principles implemented, if the information does not "come" to society? We believe 
that the answer is obvious to this question since it is difficult to imagine the observance of the principles of transparency and openness of justice outside of the proper circulation of information about the administration of justice in society. And in this sense, the opinion of O. P. Petryshyn looks convincing, who noted that the very dissemination of information through the media activates (stimulates) the implementation of the principles of transparency and openness, creates the necessary conditions for the implementation of public control over justice (Petryshyn, 2017).

Effective access to information held by judicial authorities and other subjects is an important prerequisite for preventing corruption, detecting and stopping corrupt practices. Information that is of public interest has particular importance, namely, information on the use of public funds, the disposal of state or municipal property, personal income, property, expenses, and financial obligations of judges and other public officials of judicial power. Access to information is a necessary tool for conducting journalistic investigations, stimulating civic activity in the anticorruption area (Fluri and Badrak, 2016). The Law of Ukraine "On Access to Public Information" has been in force in Ukraine since May 2011, which has been recognized as one of the best in the world in terms of the regulation (Law, 2011). At the same time, the state of practical implementation of the new provisions on access to information remains unsatisfactory since the real opportunities for access to information are too limited. There are cases of unjustified refusal for access to information on an initiative basis; there is no effective state control over the exercise of the right on the access to public information.

It should be noted that there is a widespread practice of covering the activities of courts on the Internet in the countries of the European Union. So, according to the British Guardian, the British Supreme Court officially allowed journalists to use Twitter's microblogging service to convey messages from court hearings. Now, journalists can apply for coverage of hearings in such an expeditious manner. They are also allowed to send messages from their mobile phones and use e-mail. For the first time, the public was informed through instant messaging from mobile phones about the events taking place in the courtroom during hearings in the case of Julian Assange. Previously, the United Kingdom was not allowed to use social networks in the courtroom, as well as prohibiting photographs and video during litigation. Journalists could use dictators only in exceptional cases. Liability for disrespect to the court imposed by the court itself was provided for the violation of these rules.

The Council of Europe pays particular importance to this issue, which introduced a number of principles relating to obtaining information through mass media on criminal proceedings. Thus, Recommendations No. R (2003) 13 of the Committee of Ministers of the
Council of Europe to Member States on the procedure for providing information on criminal proceedings through the mass media dated from June 10, 2003, stated that "since society should receive information on the activities of judicial power and the police through media, journalists should be able to freely talk and comment on the activities of the judicial system" (Recommendations, 2003).

These Recommendations the rights of journalists and correspondent to them responsibilities of the state, including the judicial authorities, establish as the principles. Therefore, these requirements encourage the creation of an effective system of interaction of courts with the media and can be recognized as one of the priority directions of the democratization of modern Ukraine. At the same time, one of the guarantees of keeping legality, objectivity and transparency in the administration of justice is to inform the society through the mass media about the activity of both the judicial system in the whole and individual judges. The coverage of these issues through the media forms legal awareness and legal culture in society, defines the level of its respect and trust in judicial power. In this context, it should be noted that nowadays the interaction of the Supreme Court with Ukrainian and foreign mass media, including social media, electronic Internet resources takes place in accordance with the Order of interaction of the Supreme Court with representatives of the mass media, approved by the order of the Supreme Court dated from November 7, 2018, No. 173-OD. According to this Procedure, the organization of work on the interaction of the Supreme Court with the media is carried out by the head of the department on information and communication activities (press centre) (Order, 2018).

However, in practice, there may be cases where publications in the media both do not increase the authority of judicial power and do not contribute to the growth of confidence but, on the contrary, diminish its credibility or generally harm it. Such publications can be posted in newspapers, on websites, in news agency and in TV and radio programs. Therefore, as I. S. Hrytsenko and S. V. Prylutskyi rightly note in their works, criticism of the judge's actions in media publications is an ambiguous issue (Hrytsenko and Prylutskyi, 2015). It is worth remembering that, according to the judgment of the European Court of Human Rights in the case of De Gaès and Giensels v. Belgium (1997), the court found that "judges should be protected from destructive cases by mass media having no actual basis." At the same time, if criticism of judicial problems or individual judges is based on "proper and thorough journalistic investigations, which are part of a public discussion of important social needs," there is no reason to restrict freedom of the media. Of great significance is another conclusion of the European Court: "judges must exercise prudence, which does not allow them (unlike, 
for example, politicians) to respond to sharp criticism" (Council of Judges of Ukraine, The Center for Training Judges, Association of Judges of Ukraine, 2009).

In accordance with the Recommendation CM / $\operatorname{Rec}$ (2010), 12 of the Committee of Ministers of the Council of Europe to the Member States in regard to judges: independence, efficiency and responsibilities of litigation and issues related to the administration of justice are of public interest. However, the right to receive information on judicial matters should be carried out in the light of the restrictions established in view of the independence of judicial power. In this regard, the creation of positions of the courts' counsellors or the press and public relations departments in the area of the responsibility of the courts or the councils of judges or other independent authorities is approved. Judges should exercise restraint in relations with the media. At the same time, judges cannot effectively administer justice without public confidence, as they are part of the society they serve to. They should be aware of the public expectations of the judicial system and complaints about its functioning. This could be facilitated by the availability of permanent mechanisms for obtaining such information, by created councils of judges or other independent agencies (Recommendation, 2010).

Thus, the main objective in relations between judicial power and the media is the achievement of the "golden mean", so that a judge is protected from the pressure of public opinion inspired by the conclusions of the media in the case being considered or will be considered. At the same time, society should have free access to the courtroom through mass media. As the President of the Constitutional Tribunal of Poland, Professor M. Safian, rightly pointed out, the courts should not be afraid of public opinion and should not be released from criticism of the media. The legal force and the final nature of the sentences do not exclude the possibility of such criticism since justice is one of the most important players in a public game in a democratic, rule-of-law state. It is also impossible to build the authority of the courts on prohibitions and lack of access to information. As a rule, this has a reciprocal effect (Hrytsenko and Prylutskyi, 2015; Safian, 2007). Therefore, an important condition for the openness of judicial power to the community is the availability for courtrooms and court decisions as a legal procedure that ensures the openness of the courts, predictability of court decisions and promotes the equal application of law and judicial practice. Thus, the access of mass media representatives to the public area of the Supreme Court premises and courtrooms (including the Cassation Criminal Court), where cases are heard in the open access, is carried out on general basis, taking into account the Instruction on the execution of state protection of the Supreme Court and the procedure for admitting to the object of protection, approved by the Office of the State Protection of Ukraine dated from December 13, 2017, and approved by the Chairman of the Supreme Court on December 14, 2017. In this case, the presence of media representatives at court hearings of the Supreme Court takes place without prior accreditation upon presentation of a person's identity document, except cases of conducting closed court hearings in accordance with the procedural law (Order, 2018).

Thus, journalists have the right to be present at all open court hearings and public announcements of court decisions without prior accreditation. Nevertheless, holding of photographing, video recording, broadcasting on radio and television in the courtroom during the hearings, as well as sound recording with the use of stationary equipment is allowed on the basis of a court order, which is made taking into account the opinion of the parties and the possibility of conducting such actions without prejudice to the trial (Part 6 of the Art. 27 of the CPC of Ukraine). All court decisions are publicly announced. Consequently, the presence of journalists at court hearings provides a real opportunity to get acquainted with court decisions. The right to receive a copy of a court decision under procedural law is granted only to the parties to the case. The Article 9 of the Law of Ukraine "On Access to Court Decisions" stipulates that persons who did not take part in the case may apply to the relevant court apparatus with a written application for the receipt of a copy of the decision or familiarization with it in full, if the court decision directly concerns their rights, freedoms, interests or responsibilities (Law, 2005). The law defines a certain procedure for filing and considering such applications. The decision is then taken by the appropriate official of the court apparatus. The existence of such a procedure for obtaining access to court decisions creates the formal grounds for a refusal to satisfy the mass media's request for access to such decisions. Therefore, it is worth agreeing with I. S. Hrytsenko and S.V. Prylutskyi that legislative reasons are incompatible with the general principles of openness of information and the principle of public (transparent and open) proclamation of a decision, even despite the official disclosure of court decisions, which is due to their placement on the web portal of judicial power of Ukraine in the Unified State Register of Judgments (www.court.gov.ua or at the direct address www.reyestr.court.gov.ua) (Hrytsenko and Prylutskyi, 2015).

At the same time, there are still problematic issues such as the determination of the priority of the admission of mass media representatives who perform their direct professional functions during the court hearing; the possibility of coverage and discussion (assessment) of judicial activity in the media before a judgement enter into force. Our legislator in these cases does not impose any restrictions or criteria for the legality of such actions.

The issue of the priority of access of mass media representatives to court hearings does not arise at all in the vast majority of court proceedings. However, 
litigation in the so-called "high-profile matters", which cause increased public interest, requires a solution to this issue. Therefore, according to V. V. Korol, thanks to the accreditation institution of media representatives in the courts, we can in a civilized manner, and not by the principle of "who came first" to decide on the issue of the access of journalists to the courtroom, reservation for them of a certain percentage of seats in the courtroom, which are intended for the public (Korol, 2015). However, the accreditation institution itself should not in any way narrow the rights of journalists, provided to them by the law. In this sense, the opinions of scholars have a diametrically opposite nature of the negative attitude to the procedure of accreditation (Rikhter, 2003) until its approval (Romanov and Holovanov, 2008). Therefore, sharing the opinion of V. V. Korol in general, regarding the legislative definition of the procedure for the admission of journalists and media representatives to the court hearings, but we believe that this procedure should be exclusively conciliatory in nature. Hence, the legal position of the Supreme Court regarding the accreditation of media representatives is entirely logical in the activities that are organized and not related to its procedural activities (Order, 2018).

As for another problematic issue within the professional and ethical plane, which is associated with coverage and discussion (providing evaluation) of judicial activity in the media before a judgement enters into force, then in this case, we completely share the arguments of V. V. Korol, who delineates this issue into two separate components: coverage and discussion (evaluation) in the media of the procedural activity of the court. Regarding the coverage of court proceedings within the criminal judiciary, there are no special reservations before judgement enters into force. Certain reservations arise precisely in connection with the possibility of discussing and assessing judicial activity within criminal proceedings. Thus, one of the tools for achieving the objective of a public project "Open Court" is "to provide an objective assessment of the actions of a judge, a prosecutor, a lawyer, to the level of professionalism and ethical standards by specialists with a recognized business reputation" (Korol, 2015). Based on such an "objective assessment", the project envisages the creation of a professional record of thousands of judges, prosecutors, and lawyers, exposing unprofessional activity, knowingly unlawful acts and corruption in the courts to the detriment of the interests of the state, citizens, and businesses.

In particular, some "experts" of the project provide a public assessment of judges, the selection procedure of whom remains not enough clear and public. The assessment becomes available to the general public, which clearly affects the formation of public opinion both in relation to a particular judge and in the proceedings he is considering (Korol, 2015). Therefore, we are convinced of the correctness of some opinions of the scholars, who consider that the publications before the end of a trial and the decision and proclamation in the court decision should contain only the informative orientation of the actual nature (Budnikova, 1999; Repeshko, 2009).

Finally, the positive experience of European countries should be applied to establish fruitful relations between domestic media and judges: to introduce a set of measures that will allow media representatives and judges to establish fruitful cooperation and ensure the transparency of the activities of court agencies.

In particular, it is justified: (a) the introduction of the press service and staff press secretaries in the courts; (b) the establishment of such effective forms of interaction between the judiciary and the media, such as: holding press conferences, round tables, joint conferences and seminars, contests, the allocation of special sections for speeches of court employees, the creation of public and editorial councils, holding open doors days for the media; (c) the introduction of the Institute of accreditation on professional attributes; (d) specialization of journalists; (e) establishing the liability of journalists for discrediting judicial power and its officials (Ovsiannikova, 2009).

\section{Findings}

The authors have elaborated recommendations on amendments and alterations to the Law of Ukraine "On Judiciary and Status of Judges" and the current Criminal Procedural Code of Ukraine, which are aimed at ensuring the right of a person to defence in the transparent and open criminal proceedings.

Therefore, the authors have offered to supplement Part 1 of the Art. 11 of the Law of Ukraine "On the Judiciary and Status of Judges" with the provisions on guaranteeing the right of everyone to receive information on the administration of justice and other information on judicial power in the volume, forms, and from sources provided by the law. In the absence of legally established restrictions on the provision of this information, the state is obliged to provide it to any person who such an interest.

Moreover, it is expedient to determine in Part 3 of the Art. 11 of the Law of Ukraine "On the Judiciary and Status of Judges" the mechanism of free access and participation of representatives of mass media in court proceedings, which is carried out in an open court hearing without any discrimination and preliminary accreditation. In this case, the specified legislative amendments must be synchronized with Part 1 of the Art. 27 of the CPC of Ukraine by amending the last sentence, which reads as follows: "No one shall be restricted in the right to receive information in the court about the date, time and place of a trial, which must be made public on the official web portal of the judicial power of Ukraine and about the court decisions made therein, except in cases established by the law". 
The said will promote the more effective realization of the right on transparent and open court proceedings by public and media representatives, provide public control over judicial power while executing its procedural activities, and guarantee the right of everyone to receive information on the administration of justice in line with European standards.

\section{Conclusions}

Consequently, we can state the interconnectedness of the effective implementation of the principles of transparency and openness of criminal proceedings and the restoration of trust in the judicial system by civil society. The principles of transparency and openness, for the public, are an important prerequisite for exercising control over the judiciary and an effective tool for preventing corruption, detecting and stopping corrupt practices. In turn, public control is one of the ways for citizens to participate in the state administration.

Access to information circulating in the judicial system and the administration of justice is a necessary tool for conducting journalistic investigations and encouraging civic activism in the anti-corruption area.

Notice of scheduled court hearings in courts of all instances, indictments, and other information related to legal issues should be made available to the public and journalists at the simple request of the competent authority within the prescribed time limit unless the provision of such information is feasible. At the same time, journalists, media representatives should be allowed to make or receive copies of publicly announced decisions on equal terms. They should be able to distribute or announce such decisions to the public. At the same time, the right to receive information on litigation should be carried out in regard to the restrictions imposed by the independence of the judiciary.

Due to the analogy of the use of the institution of accreditation of media representatives and journalists in the courts, it is possible to solve the issue of their access to the courtroom in a civilizational manner, reserving for them a certain percentage of seats in the courtroom, which are intended for the public. A detailed procedure for admitting journalists, media employees in the courts should be regulated in the legislation on the judicial system.

It is also expedient to pay special attention, among the measures to counteract corruption and illegal enrichment within the judiciary, to the selection of candidates for positions of judges. This procedure should be carried out in accordance with the list of indicators for determining the inconsistency of judges with criteria of integrity and professional ethics developed and approved by the Public Council of Integrity.

However, a number of issues within the subject of the research remains unresolved. In particular, Art. 3682 of the Criminal Code of Ukraine (Illegal Enrichment) (Code, 2001), which may be an effective mechanism for the deprivation of illegally acquired property from offenders in judicial robes, should comply with the Art. 20 of the United Nations Convention against Corruption (Convention, 2003). Simultaneously with criminal and legal instruments for bringing to liability for the illegal enrichment of judges (other persons within judicial power), it is also necessary to introduce civil and legal instruments for the collection of the property, the legal origin of which a person cannot prove according to the established procedure by law by the prosecutor's claim (specially authorized anti-corruption agency) into the income of the state.

Further scientific developments also require issues regarding the practical determination of the priority of admission of mass media representatives, who during their judicial session perform their direct professional functions; the possibility of coverage and discussion (assessment) of judicial activity in the media before a court decision enters into force.

\section{References:}

Relevant problems of Ensuring Publicity of Judicial Power. URL: http://advocat-cons.info/index. php?newsid=14166\#.WnWTH651_cs

Boikov, A. D. (1989). Glasnost i pravosudie [Publicity and Justice]. Sovetskoie hosudarstvo i pravo, 8, 14.

British Journalists Will Highlight Trials with the Help of Twitter. URL: http://www.telekfltika.ua/news/2010-1220/58554

Budnikova, L. I., \& Budnikov, V. L. (1999). Glasnost ugolovnogo sudoproizvodstva [Publicity of Criminal Proceedings]. Mass Media and Legal Culture of Population: materials of International scientific and practical conference. Volhohrad : Volhohrad Law Institute of the Ministry of Internal Affairs of Russia.

Open Court // Official portal. URL: http://open-court.org

Leonenko, V. V., Miller, A. I., Siryi, N. I., \& Chanhuli, H. I. (1993). Publicity of Court Activity on Criminal Cases: [manual]. Kyiv: Nauk. dumka.

Hrytsenko, I. S., \& Prylutskyi, S. V. (2015). Vplyv hromadianskoho suspilstva na stanovlennia sudovoi vlady v Ukraini [Influence of Civil Society on the Establishment of Judicial Power in Ukraine]. Visnyk kryminalnoho sudochynstva, 2, 214-222.

Hrytsenko, I. S., \& Prylutskyi, S. V. (2015). Sudova vlada i hromadianske suspilstvo [Judicial Power and Civil Society]: the Concept of Interaction. Visnyk kryminalnoho sudochynstva, 1, 241-249. 
Hroshevoi, Yu. M. (1972). Obshestvennoe mnenie i prigovor sovetskogo suda [Public Opinion and the Verdict of the Soviet Court] : Lecture notes. Kharkiv.

Reference Information for Citizens on the Activities of the Cassation Criminal Court within the Supreme Court. URL: https://supreme.court.gov.ua/supreme/pro sud/dovidkova info dlya gromadyan kks/

Zakon Ukrainy vid 2 chervnia 2016 roku № 1402-VIII «Pro sudoustrii i status suddiv» (stanom na 12.07.2018 r.) [Law of Ukraine dated from June 2, 2016. No. 1402-VIII “On Judiciary and Status of Judges” (as of July 12, 2018)]. Vidomosti Verkhovnoi Rady Ukrainy. 2016. No. 31. Art. 545.

Zakon Ukrainy vid 7 lypnia 2010 roku № 2453-VI «Pro sudoustrii i status suddiv» [Law of Ukraine dated from July 7 , 2010. No. 2453-VI “On Judiciary and Status of Judges”]. Vidomosti Verkhovnoi Rady Ukrainy. 2010. No. 41-42. Art. 529.

Zakon Ukrainy vid 14 zhovtnia 2014 roku № 1700-VII «Pro zapobihannia koruptsii» [Law of Ukraine dated from October 14, 2014. No. 1700-VII “On Prevention of Corruption”]. Vidomosti Verkhovnoi Rady Ukrainy. 2014. No. 49. Art. 2056.

Zakon Ukrainy vid 22 hrudnia 2005 roku № 3262-IV «Pro dostup do sudovykh rishen» (stanom na 3.10 .2017 r.) [Law of Ukraine dated from December 22, 2005. No. 3262-IV “On Access to Judgements" (as of October 3, 2017)]. Vidomosti Verkhovnoi Rady Ukrainy. 2006. No. 15. Art. 128.

Zakon Ukrainy vid 13 sichnia 2011 roku № 2939-VI «Pro dostup do publichnoi informatsii» (stanom na 9.04.2015 r.) [Law of Ukraine dated from January 13, 2011. No. 2939-VI "On Access to Public Information" (as of April 9, 2015)]. Vidomosti Verkhovnoi Rady Ukrainy. 2011. No. 32. Art. 314.

Zakony Ukrainy vid 2 zhovtnia 1992 roku № 2657-KhII «Pro informatsiiu» v redaktsii Zakonu Ukrainy vid 13.01.2011 r. № 2938-VI (stanom na 06.12.2016 r.) [Laws of Ukraine dated from October 2, 1992. No. 2657-XII "On Information" in the edition of Law of Ukraine dated from January 13, 2011. No. 2938- VI (as of December 6, 2016)]. Vidomosti Verkhovnoi Rady Ukrainy. 2011. No. 32. Art. 313.

Zakon Ukrainy vid 8 kvitnia 2014 roku № 1188-VII «Pro vidnovlennia doviry do sudovoi vlady v Ukraini» (stanom na 21.12.2016 r.) [Law of Ukraine dated from April 8, 2014. No. 1188-VII "On Restoring Trust to Judicial Power in Ukraine" (as of December 21, 2016)]. Vidomosti Verkhovnoi Rady Ukrainy. 2014. No. 23. Art. 870.

Zakon Ukrainy vid 12 liutoho 2015 roku № 192-VIII «Pro zabezpechennia prava na spravedlyvyi sud» (stanom na 21.12.2016 r.) [Law of Ukraine dated from February 12, 2015. No. 192-VIII "On Guaranteeing the Right to Fair Trial” (as of December 21, 2016)]. Vidomosti Verkhovnoi Rady Ukrainy. 2015. No. 18, No. 19-20. Art. 132.

Zakon Ukrainy vid 23 liutoho 2006 roku № 3477-IV «Pro vykonannia rishen ta zastosuvannia praktyky Yevropeiskoho sudu z prav liudyny» (stanom na 16.10.2012 r.) [Law of Ukraine dated from February 23, 2006. No. 3477-IV "On Execution of Judgements and Implementation of the Practice of the European Court of Human Rights" (as of October 16, 2012)]. Vidomosti Verkhovnoi Rady Ukrainy. 2006. No. 30. Art. 260.

Zakon Ukrainy «Pro ochyshchennia vlady» (stanom na 21.12.2017r.) vid 16 veresnia 2014 roku № 1682-VII [Law of Ukraine "On Purification of Power" (as of December 21, 2017) dated from September 16, 2014. No. 1682-VII]. Vidomosti Verkhovnoi Rady Ukrainy (VVR). 2014. No. 44. Art. 2041.

Konventsiia pro zakhyst prav liudyny i osnovopolozhnykh svobod vid 4 lystopada 1950 roku [Convention for the Protection of Human Rights and Fundamental Freedoms dated from November 4, 1950]. URL: http://zakon0.rada.gov.ua/laws/show/995_004

Konventsiia Orhanizatsii Obiednanykh Natsii proty koruptsii 2003 roku: ratyfikovana Zakonom Ukrainy vid 18.10.2006 № 251-V [UN Convention against Corruption of 2003: ratified by the Law of Ukraine dated from October 18, 2006. No. 251-V]. Vidomosti Verkhovnoi Rady Ukrainy. 2006. No. 50. Art. 496.

Konstytutsiia Ukrainy [Constitution of Ukraine]. URL: http://zakon2.rada.gov.ua/laws/show/254к/96-вр

Korol, V. V. (2015). Suchasni formy hromadskoho kontroliu v sudakh i yikh vplyv na realizatsiiu zasadnychykh polozhen hlasnosti y vidkrytosti kryminalnoho provadzhennia [Modern Forms of Public Control in Courts and Their Influence on the Implementation of the Basic Principles of Transparency and Openness of Criminal Proceedings]. Prykarpatskyi yurydychnyi visnyk, 3(9), 291-296.

Korol, V. V. (2015). Orhanizatsiini ta protsesualni formy realizatsii zasady hlasnosti i vidkrytosti kryminalnoho provadzhennia [Organizational and Procedural Forms of Implementing the Principle of Transparency and Openness of Criminal Proceedings]. Pravo i suspilstvo, 4(2), 185-192.

Korol, V. V. (2003). Zasada hlasnosti kryminalnoho sudochynstva Ukrainy: poniattia, zmist, pidstavy obmezhennia [Principle of Publicity of Criminal Proceedings of Ukraine: Concept, Content, Reasons for Restriction]. IvanoFrankivsk: Plai.

Hroshevyi, Yu. M., Tatsii, V. Ya., Tumaniants, A. P., and others (2013). Kryminalnyi protses [Criminal Procedure]: textbook. Kharkiv: Pravo.

Kryminalnyi protsesualnyi kodeks Ukrainy vid 13 kvitnia 2012 roku № 4651-VI (stanom na 16 lystopada 2017 roku) [Criminal Procedural Code of Ukraine dated from April 13, 2012. No. 4651-VI (as of November 16, 2017)]. Vidomosti Verkhovnoi Rady Ukrainy. 2012. No. 9-10, No. 11-12, No. 13. Art. 88. URL: http://zakon3.rada.gov.ua/ laws/show/4651-17/print1487012800234384

Kryminalnyi kodeks Ukrainy vid 5 kvitnia 2001 roku [Criminal Code of Ukraine dated from April 5, 2001]. Vidomosti Verkhovnoi Rady Ukrainy. 2001. No. 25-26. Art. 131.

Levi, A. A., \& Horinov, Yu. A. (1983). Zvukozapis i videozapis v ugolovnom sudoproizvodstve [Sound Recording and Video Recording in Criminal Proceedings]. Moskva: Yurid. lit. 
Leonenko, V. V., Miller, A. I., Siryi, N. I., \& Chanhuli, H. I. (1993). Glasnost sudebnoj deyatelnosti po ugolovnym delam [Publicity of Court Activity on Criminal Cases]. Kyiv: Naukova dumka. (in Ukrainian)

Makarova, Z. V. (1993). Glasnost ugolovnogo processa [Publicity of Criminal Proceedings] : monograph. Under edition of Z. Z. Zinatulina. Cheliabinsk: ChHTU.

Maliarenko, V. T. (1998). Hlasnist sudovoho protsesu ta yoho povne fiksuvannia tekhnichnymy zasobamy yak odna iz osnovnykh konstytutsiinykh zasad kryminalnoho sudochynstva [Publicity of Criminal Proceedings and Its Complete recording by Technical Means as One of the Main Constitutional Principles of Criminal Justice]. Visnyk Verkhovnoho Sudu Ukrainy, 4(10), 26-33.

Nakaz Derzhavnoi sudovoi administratsii Ukrainy vid 6 travnia 2011 roku № 93 «Pro zatverdzhennia Polozhennia pro poriadok orhanizatsii dostupu do publichnoi informatsii, shcho znakhodytsia u volodinni Derzhavnoi sudovoi administratsii Ukrainy [Order of the State Judicial Administration of Ukraine dated from May 6, 2011. No. 93 "On Approval of the Regulation on the Procedure for the Organization of Access to Public Information in the Possession of the State Judicial Administration of Ukraine"]. URL: http://dsa.court.gov.ua/dsa/pybinf/ndsa19/

Nakaz Derzhavnoi sudovoi administratsii Ukrainy vid 17 hrudnia 2013 roku № 173 «Pro zatverdzhennia Instruktsii z dilovodstva v mistsevykh zahalnykh sudakh, apeliatsiinykh sudakh oblastei, apeliatsiinykh sudakh mist Kyieva ta Sevastopolia, Apeliatsiinomu sudi Avtonomnoi Respubliky Krym ta Vyshchomu spetsializovanomu sudi Ukrainy z rozghliadu tsyvilnykh i kryminalnykh sprav» [Order of the State Judicial Administration of Ukraine dated from December 17, 2013. No. 173 "On Approval of the Instruction on Records Management in Local General Courts, Regional Appeal Courts, Appellate Courts of Kyiv and Sevastopol, the Court of Appeal of the Autonomous Republic of Crimea and the Supreme Specialized Court of Ukraine on Civil and Criminal Cases"]. URL: http://dsa.court.gov.ua

Ovsiannikova, O. O. (2009). Transparentnist sudovoi vlady [Transparency of Judicial Power]: Synopsis of a thesis ... candidate of law sciences by specialty 12.00.10 - judiciary; prosecutor's office and the bar. Kharkiv.

Ovsiannikova, O. O. (2008). Transparentnist sudovoi vlady: poniattia ta zmist [Transparency of Judicial Power: Concept and Content]. Visnyk Akademii pravovykh nauk Ukrainy, 4(55), 228-237.

Petryshyn, A. P. (2017). Konstiucionno-pravovye osnovy glasnosti pravosudiya v Rossii [Constitutional and Legal Basis of Justice Transparency in Russia]: dissertation for a candidate of law sciences : specialty 12.00 .02 "Constitutional Law; constitutional court proceedings; municipal law". Moscow.

Petrukhin, I. L. (1981). Glasnost sudoproizvodstva [Publicity of Judicial System]. Constitutional Basis in the USSR. Moskva: Nauka.

Poriadok vzaiemodii Verkhovnoho Sudu z predstavnykamy zasobiv masovoi informatsii: nakaz Verkhovnoho Sudu vid 7 lystopada 2018 roku № 173-OD [Interaction Procedure between the Supreme Court and Mass Media Representatives: order of the Supreme Court dated from November 7, 2018. No 173-OD]. URL: https://supreme.court.gov.ua/supreme/pres-centr/vzaemodiya/

Pohoretskyi, M. A., \& Yanovska, O. H. Vidkrytist ta prozorist sudovoi systemy: problemy realizatsii mizhnarodnykh standartiv v Ukraini [Transparency and Openness of the Judicial System: Problems of Realization of International Standards in Ukraine]. URL: http://lcslaw.knu.ua/index.php/arkhiv-nomeriv/2-3-2013/item/111-vidkrytist-taprozorist-sudovoi-systemy-problemy-realizatsii-mizhnarodnykh-standartiv-v-ukraini-pohoretskyi-m-a-yanovska-o-h Praskova, S. V. (2004). Teoreticheskie osnovy glasnosti pravosudiya [Theoretical Basis of Justice Publicity]: Synopsis of a thesis ... candidate of law sciences]. Moskva.

Rada suddiv Ukrainy, Tsentr suddivskykh studii, Asotsiatsiia suddiv Ukrainy (2009). Rehionalna model zmitsnennia nezalezhnosti suddiv [Regional Model of Strengthening Independence of the Judges: Practical manual for Judges commissions]. Collective of authors, Judges Commission of Ukraine, The Center of Judges Groups, Association of Ukrainian Judges. Kyiv: Polihraf-Ekspres.

Rekomendatsii vid 10 chervnia 2003 roku № R (2003). 13 Komitetu ministriv Rady Yevropy derzhavam-chlenam pro poriadok nadannia informatsii pro provadzhennia u kryminalnykh spravakh cherez zasoby masovoi informatsii. Verkhovna Rada Ukrainy [Recommendations dated from June 10, 2003. № R (2003) 13 of the Committee of Ministers of the Council of Europe to Member States on the procedure for providing information on criminal proceedings through the mass media]. URL: https://zakon.rada.gov.ua/laws/show/994_870

Rekomendatsiia CM/Rec (2010). 12 Komitetu ministriv Rady Yevropy derzhavam-chlenam shchodo suddiv: nezalezhnist, efektyvnist ta oboviazky. Verkhovna Rada Ukrainy [Recommendation CM/Rec (2010) 12 of the The Committee of Ministers of the Council of Europe to Member States on judges: independence, efficiency and responsibilities]. URL: http://zakon1.rada.gov.ua/cgi-bin/laws/main.cgi?nreg=994_a38

Repeshko, P. I. Osveshenie v SMI sudebnyh processov kak sredstvo obespecheniya otkrytosti i glasnosti sudoproizvodstva (ukrainskij opyt) [Media Coverage of Court Processes as a Mean of Ensuring Transparency and Publicity of the Judiciary (Ukrainian Experience)]. URL: http://www.medialaw.kiev.ua/zmisud/ sudanalityka/226/

Rishennia Vyshchoi rady pravosuddia vid 19 kvitnia 2018 roku № 1200/0/15-18 «Pro zatverdzhennia Poriadku vedennia Yedynoho derzhavnoho reiestru sudovykh rishen» [Resolution of the High Council for Justice dated from April 19, 2018. No. 1200/0/15-18 "On Approval of the Procedure of Operating the Unified State Register of Court Decisions"]. URL: https://zakon.rada.gov.ua/rada/show/v1200910-18

Rikhter, A. H. (2003). Glasnost pravosudiya i prava zhurnalistov [Transparency of Justice and Rights of Journalists]. Legislation and Practice of Mass Media, 12, 13-17. 
Romanov, S. V., \& Holovanov, D. A. Princip glasnosti ugolovnogo sudoproizvodstva i sredstva massovoj informacii: istoricheskoe razvitie i sovremennaya problematika [Principle of Publicity of Criminal Proceedings and Mass Media: Historical Development and Modern Problems]. URL: http://www.medialaw.kiev.ua/zmisud/sudanalityka/197/

Marek Safian (2007). Rol suddiv pry pobudovi hromadianskoho suspilstva [The Role of Judges in Building Civil Society]. Judiciary and Judicial System in Ukraine, 7, 114-121.

Sida, Yu. S. (2005). Sudova vlada v umovakh transformatsii ukrainskoho suspilstva [Judicial Power in Terms of Transformation of Ukrainian Society]: Synopsis of a thesis ... candidate of sociological sciences: by specialty 22.00.04. V. N. Karazin Kharkiv National University. Kharkiv.

Smirnov, A. V. Problemy otkrytosti sudebnoj vlasti dlya grazhdanskogo obshestva. Ekspertnoe issledovanie na osnove pravoprimenitelnoj praktiki ugolovnyh sudov Sankt-Peterburga i Leningradskoj oblasti [Problems of Trasparency of Judicial Power for Civil Society. Expert research based on law-enforcement practice of criminal courts of St. Petersburg and Leningrad region]. URL: http://www.kalinovsky-k.narod.ru/b/sav-tr0.htm

Smirnov, A. V. Publichnost (otkrytost) sudebnoj vlasti kak uslovie demokratii v Rossii [Publicity (Openness) of Judicial Power as the Condition for Democracy in Russia]. URL: http://kalinovsky-k.narod.ru/b/st/smirnov2004.htm

Staly vidomi indykatory vyznachennia nevidpovidnosti suddiv kryteriiam dobrochesnosti [Indicators for Determining the Inconsistency of Judges with the Criteria of Integrity Became Known]. Tsentr suddivskykh studii, 2019. URL: http://judges.org.ua/crime/www.law.indiana.edu/dig15567.htm

Judicial Power of Ukraine: Official web portal. URL: http://court.gov.ua

Fluri, F., \& Badrak, V. (2016). Antykoruptsiini zakhodyv Ukraini pislia Revoliutsii Hidnosti : kliuchovi zakonodavchi aspekty [Anticorruption Measures in Ukraine after the Revolution of Dignity : Key Legislative Aspects]. Kyiv.

Shushanashvili, A. A. (1969). Glasnost v sovetskom ugolovnom processe [Publicity within Soviet Criminal Procedure]. Tbilisi. 